Volume 9, No.3, May - June 2020

International Journal of Advanced Trends in Computer Science and Engineering

Available Online at http://www.warse.org/IJATCSE/static/pdf/file/ijatcse20932020.pdf

https://doi.org/10.30534/ijatcse/2020/20932020

\title{
Development of Game Open Online Physics Instructional (GOOPI) for Improving 21st-Century Careers: Creativity Skill (21-CC:CS)
}

\author{
Firmanul Catur Wibowo ${ }^{1}$, Hadi Nasbey ${ }^{2}$, Lari Andres Sanjaya ${ }^{3}$, Dina Rahmi Darman ${ }^{4}$ \\ ${ }^{1}$ Department of Physics Education, Universitas Negeri Jakarta, Jakarta Timur 13220, Indonesia, \\ fcwibowo@unj.ac.id \\ ${ }^{2}$ Department of Physics Education, Universitas Negeri Jakarta, Jakarta Timur 13220, Indonesia, \\ hadinasbey@unj.ac.id \\ ${ }^{3}$ Department of Physics Education, Universitas Negeri Jakarta, Jakarta Timur 13220, Indonesia, \\ lari@unj.ac.id \\ ${ }^{4}$ Department of Physics Education, Universitas Sultan Ageng Tirtayasa, Serang 42117, Indonesia, \\ dina_rd@untirta.ac.id
}

\begin{abstract}
Physics essentially develops a curious attitude, and there is a development towards a positive attitude in the face of the industrial 4.0 revolution in the world of Education. The positive dimension in Physics Instructional can be developed through Online Game (OG) learning activities or online courses, students can learn the principles and concepts of science in accordance with the level of understanding to develop higher-level thinking skills, one of which is 21st-century careers: creativity skill. However, in general Physics learning is still more focused on aspects of physical products, while aspects of scientific processes and attitudes that should be trained through learning activities are often ignored [23]. In addition, there is no online course specifically transformed in the form of OG to train on the concepts of physics concepts. If students are facilitated by OG to study physics, then physics concepts that are considered difficult will be easy to understand. The purpose of the study was to produce an Open Online Physics Instructional (GOOPI) Development for Improving 21st-Century Careers: Creativity Skills (21 CC: CS). The research method used is the ADDIE Model which consists of the stages of Analysis, Design, Develop, Implement, and Evaluate. Subjects were 120 students aged 19-20 years. The results showed an increase of $21 \mathrm{CC}$ : CS students in the moderate category After learning to use GOOPI, this significant improvement showed the effectiveness of GOOPI in facilitating student learning to improve creative thinking skills. The conclusion of this study is the Open Online Physics Instructional Game for Improving 21st-Century Careers: Creativity Skills.
\end{abstract}

Key words: Open Online Physics Instructional Games (GOOPI), Improving, 21st-Century Careers, Creativity Skills (21-CC:CS).

\section{INTRODUCTION}

Education 4.0 is a phenomenon that responds to the needs of the fourth industrial revolution, where humans and machines are aligned to get solutions, solve problems, and of course discovers new possibilities for innovation [2]. Basic education to higher education, adjusting the education curriculum with the challenges and needs of the current era. A curriculum that opens access for millennials to gain knowledge and training to become competitive and productive workers. Speaking of the problem of the industrial revolution 4.0 and its relation to education, of course the education world is the main and central thing to follow the flow of the industrial revolution, because it will print and produce quality generations. Education in the era of the industrial revolution 4.0 took the form of a change in the way of learning, thinking, and the way students act in developing creative innovations in various fields [1].

Higher education should adjust to building a mindset towards students and the academic community in preparing students to face internal and external challenges at 21 st-Century Careers [17]. The challenge is in the form of educational demands which must still refer to the National Education Standards [22]. Other challenges include global issues with the birth of the AEC and the transformation of the education sector towards the industrial revolution 4.0. This demand is in line with the target of learning achievement in the curriculum of higher education based on learning achievement must include aspects of attitude and values, knowledge, and skills according to descriptors to be able to apply their fields of expertise and utilize science and technology in their fields [7] [24].

Physics learning that explains natural phenomena is formed when there is an interaction between matter (matter) with energy [11]. For example, in everyday life there is an observed phenomenon that is the increase in temperature of the substance when heated [19]. If the concept of physics can be understood through visual activities, it will be easy to understand. The concept of physics can be easily understood 
if done with fun and practice critical thinking and problem solving, communicating, collaborating, and being creative and innovative, creative thinking skills [18]. These skills focus on creativity, critical thinking, communication and collaboration which are referred to as 21 st-century skills which are very important to prepare students for a more complex life and work environment [20]. Teachers themselves should be able to design, implement and evaluate creative ideas, provide learning experiences that will attract students and enhance learning, enrich professional experiences as teachers of the 21st century [3].

Based on field studies obtained information that the lowest average score of creative thinking skills at the time of the final test occurred during the activity to improve the output of 1.97 from the ideal score 3 . The average score of the final test of creative thinking skills in the questioning activity was 4.09 from the ideal score of 6 The average final test score of creative thinking skills in guessing activities due to an event, is 4.15 from the ideal score 6 . The highest average score of the final test occurs on the guessing activity because of an event in 9.50 from the ideal score 15. Obtained information that the low creative thinking skills of students to physics teaching materials and can be categorized as low.

The development of the various Game Online Instructional (GOI) media or online games for learning so far has been done for the sake of learning physics, including: enabling students to apply their strategies and prior knowledge to solve problems through Online Games [4] [6]. Digital games can involve student activity, motivation and learning outcomes [15] [8]. Educational games increase student interest in continuous motivation, practicing certain behaviors that might be critical strategies [5], [4] [13]. Game-based learning is considered to have potential in a learning environment based on several key aspects: giving students' challenges allows students to combine prior knowledge from different aspects to make meaningful decisions, and encourage students to predict what will be the outcome of their decisions and actions [8]. Learning only through the process of listening alone (lectures) without doing anything else such as taking notes, then contributing to the mastery of the material is only $5 \%$. If it is followed by reading, then it contributes to the mastery of the material by $10 \%$ and when learning with audio-visual assistance, it will contribute to the mastery of the material by $30 \%$ [9]. The results of these studies indicate that if students can see visually the material of physics, students will be easier to understand and will avoid the construction of the wrong conception.

Open Online Physics Instructional (GOOPI) Game media that can make microscopic phenomena that cannot be seen become phenomena that can be seen through the games. For example, the temperature of a substance is microscopically described by the rate of movement of the constituent particles. The higher the temperature of an object, the faster the motion of its feeding particles. Because the particle size of the constituents of substances is very small and cannot be observed in the sense of sight, their movements cannot be observed or understood [21].
The virtue of this superior research is that in developing GOOPI it is believed that it will greatly assist in the conception, construction process in learning physics, especially to facilitate creative thinking skills. Therefore, researchers are interested in developing GOOPI which currently has not been developed by other researchers in the hope that they can make a real contribution in improving the quality of physics learning at various levels of secondary and tertiary levels through the provision of one of the supporting devices for learning physics in the form of Online Games.

The development of GOOPI research to train creative thinking skills can contribute to science, namely (1) the developed GOOPI media can build students' scientific conceptions, so that when they become physics teachers the concepts are correct so that no concept errors occur in the students being taught. If students have the wrong concept, then the student is wrong in understanding the concept of physics will result in lower ability of science in Indonesian society. (2) If the community in Indonesia is low, it will result in a low ability to think science which will cause the Community Development Index will also be low. (3) The real contribution of GOOPI research development is the increasing number of international publication articles indexed by Scopus, because current research in the world of education is developing rapidly, especially assisted in the development of computer-based media and will ultimately support national development.

However, Instructional Online Games that have been developed have not demonstrated or practiced both microscopic and microscopic concepts of physics to enhance creative thinking skills. The purpose of the study was to produce an Open Online Physics Instructional (GOOPI) Development for Improving 21st-Century Careers: Creativity Skills (21 CC: CS).

\section{METHODOLOGIES}

This type of research used in this study is a research and development (R\&D) oriented to product development. This research design refers to several stages of the development research model. This ADDIE model is an abbreviation for the five stages of the development process, namely Analysis, Design, Develop, Implement, and Evaluate. The ADDIE model relies on each stage carried out in the order given, but with a focus on reflection and iteration. This model gives you an approach that focuses on providing feedback for continuous improvement. The results of applying e-learning information technology with ADDIE Model can, among other things, enrich the instructor's pedagogy in learning activities and can overcome the constraints of interaction in teaching and learning activities. In the distribution of learning materials can be done more effectively and the teaching and learning process is also not constrained by the problem of time and place while there is good internet network connectivity, can interact using chatting facilities, can utilize audio facilities when interacting in the learning process [14]. 


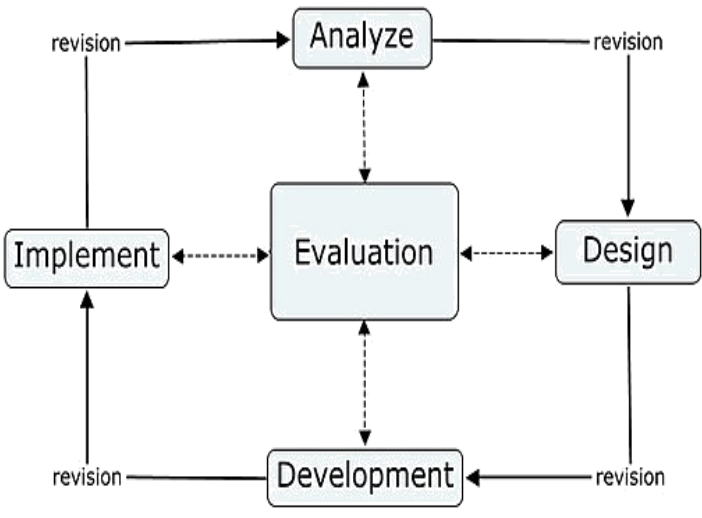

Figure 1: ADDIE Model Design

The initial step to find out the mastery of the concept at the beginning of lectures, initial measurements. Furthermore, the results of these initial measurements are analyzed which parts of the concept still occur microscopically. Qualitative data when it is measured can be collected through field notes and documentation in the form of sound or video recordings which are then transcribed to see the types of creative thinking skills. The detailed information gathering was also carried out by semi-open interviews after initial measurements. The results of the analysis of creative thinking skills in the initial measurements, then students of research subjects treat in the form of learning with GOOPI which focuses on the construction of scientific conceptions on microscopic material to change and improve the creative thinking skills experienced by students. After the treatment the final measurement is given with a final test to see if there are changes in creative thinking skills that can be effectively reduced by GOOPI. To establish an analysis of his creative thinking skills, a semi-open interview was also conducted after the final measurements were made. To see changes, in creative thinking skills used an instrument of creative thinking skills in the form of description to see how much creative thinking skills change. The final conclusions are obtained from quantitative data analysis that is complemented by qualitative and final data analysis

Table 1: 21st-Century Careers: Creativity Skills (21 CC: CS) Indicators and Activity

\begin{tabular}{|l|c|}
\hline \multicolumn{1}{|c|}{$\begin{array}{c}\text { CTS } \\
\text { Indicator }\end{array}$} & Activity \\
\hline Ask questions & $\begin{array}{c}\text { [1] Students are asked to develop as } \\
\text { many questions as possible about } \\
\text { the things that occur in the } \\
\text { pictures provided }\end{array}$ \\
\hline $\begin{array}{l}\text { Guess the } \\
\text { causes }\end{array}$ & $\begin{array}{l}\text { [2] Students are asked to guess as } \\
\text { much as possible the sources of } \\
\text { the causes of the events shown in } \\
\text { the picture }\end{array}$ \\
\hline $\begin{array}{l}\text { Assess the } \\
\text { consequences } \\
\text { of an event }\end{array}$ & $\begin{array}{l}\text { [3] Students are asked to predict as } \\
\text { many of the consequences that } \\
\text { will occur, causing by the events } \\
\text { shown in the picture }\end{array}$ \\
\hline
\end{tabular}

\begin{tabular}{|l|c|}
\hline \multicolumn{1}{|c|}{$\begin{array}{c}\text { CTS } \\
\text { Indicator }\end{array}$} & Activity \\
\hline $\begin{array}{l}\text { Improve the } \\
\text { outputs }\end{array}$ & $\begin{array}{l}\text { [4] Students are asked to express the } \\
\text { best and extraordinary ways to } \\
\text { change the form given in a form } \\
\text { that is more tangible and easier to } \\
\text { understand }\end{array}$ \\
\hline $\begin{array}{l}\text { Exceptional } \\
\text { use }\end{array}$ & $\begin{array}{l}\text { [5] Students are asked to write down } \\
\text { as many uses of an object as } \\
\text { possible }\end{array}$ \\
\hline Forecasting & $\begin{array}{l}\text { [6] Students are asked to write down } \\
\text { other things that will also occur as } \\
\text { a result of an event. }\end{array}$ \\
\hline
\end{tabular}

\section{RESULT AND DISCUSSION}

\subsection{GOOPI Development}

The display will be seen after clicking the game tab on the previous screen. On the main menu display, there are a button "basic competence, goals, basic theory, simulation, and logout. The "basic competency" button functions to display the basic competencies on the subject of substance Change. "Purpose" button to display learning objectives. The "basic theory" button to display substance Change is a change in substances that occur thermodynamically from one form of substance to another. Substitution of these substances can occur due to the release or absorption of heat. There are several criteria for each form of different substances, namely Liquid, Solid, and Gas. The moos are on the page: http://moocsvms.com/.

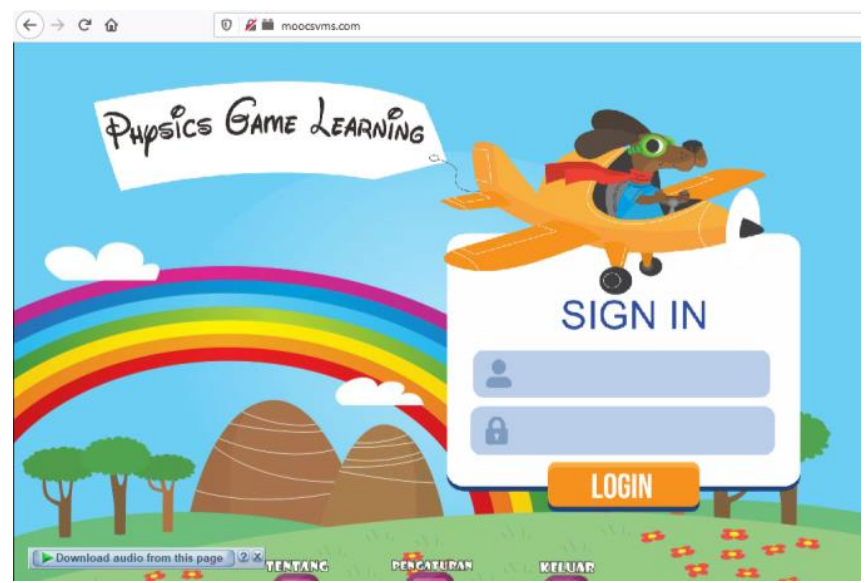

Figure 2: Development of Display GOOPI

Based on figure 2. On the display, you can see that there is a media title, physics game learning, a username column that is filled in and a password column filled in. Some navigation buttons that have different functions if clicked it will go to the screen of each button. The navigation button about where if clicked, will display physics game learning information, the compiler's self-data and bibliography as above. The home button if clicked, will return to the login menu.

The above display will appear when the user clicks on the settings button. Settings containing a Fullscreen button that can be clicked on the yellow check will change the display to 
full on the desktop if the checkmark disappears, the media display will not be full. Clickable music button functions to turn on and turn off existing music.

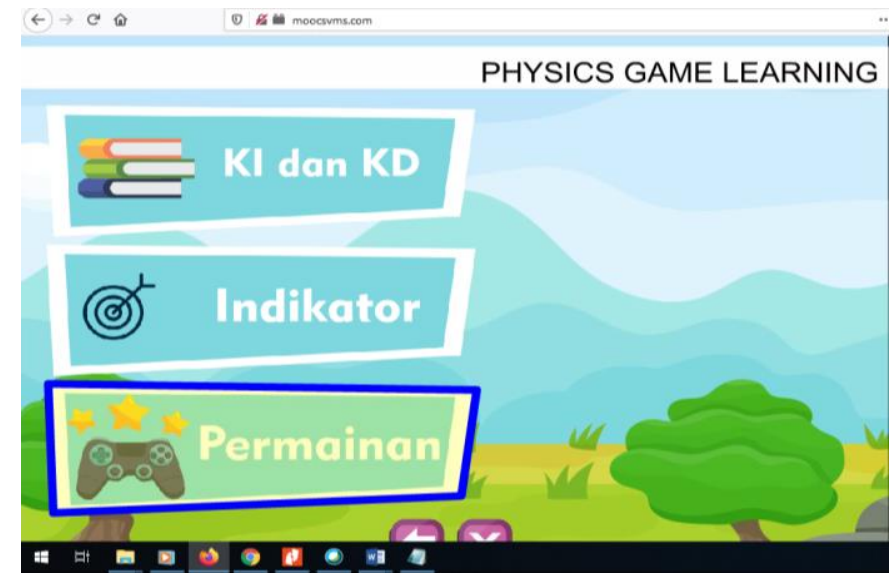

Figure 3: Display of Convection MOOS Microscopic

Based on Figure 3. The information after clicking on the Indicator tab. The display on the screen contains an explanation of the third core competency and basic competency. There is an arrow button when clicked, will return to the login menu and $\mathrm{X}$ button to exit the media. The above display will be seen after clicking on the Indicators tab. Display on the screen contains an explanation of the indicators contained in media that have been developed that explains the heat relationship with the temperature of objects and their shapes, analyze the effect of heat on the temperature and shape of objects. There is an arrow button when clicked, will return to the login menu and $\mathrm{X}$ button to exit the media.

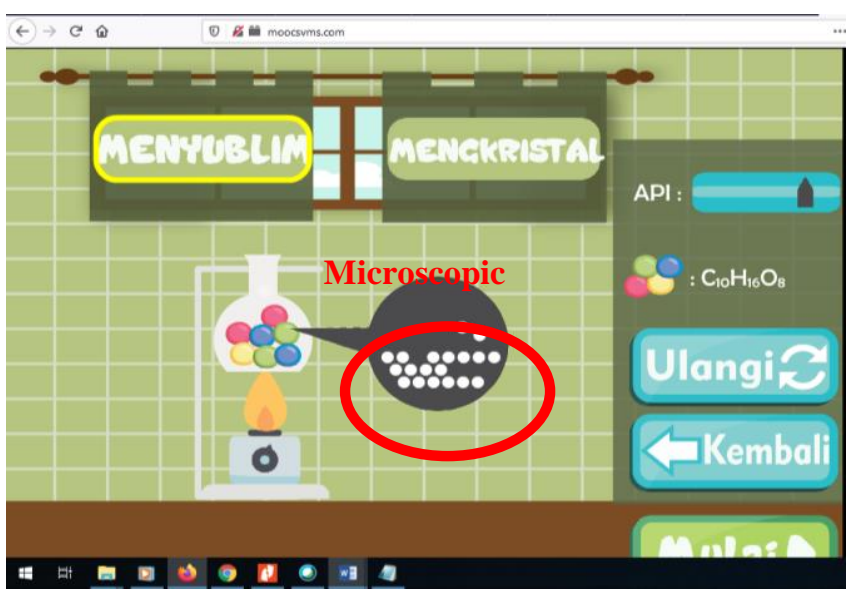

Figure 4: Display of Radiation MOOS Microscopic

The screen display above shows camphor in the test tube with a neat arrangement of particles. The user moves the fire parameters before starting to run the simulation and click start to begin the process of changing the form of camphor. After the process is running, the longer the shape of mothballs shrink and disappear, accompanied by the movement of particles that get faster and release into the air. When all the mothballs are gone the stove goes out, click the repeat button to try again.

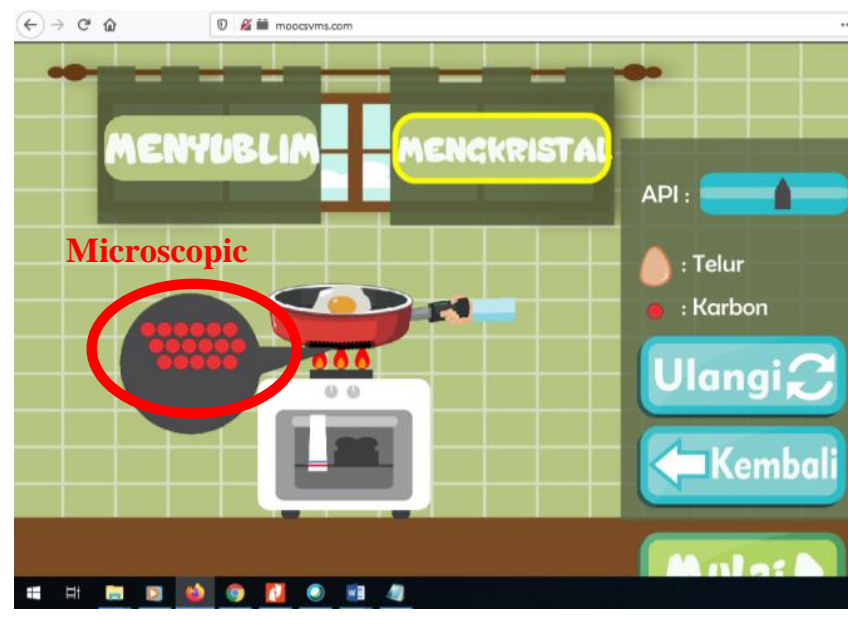

Figure 5: Display of Radiation MOOS Microscopic

The above display shows the crystallization process through a simulation of cooking eggs in a heated pan. The first step the user set the parameters of the fire, then click start to run the cooking process. When the cooking process takes place, there is blackening under the pan which is caused by the stove fire which removes carbon and sticks. When more and more carbon is seen the movement of particles that begin to be arranged and bound then the simulation is complete and the stove goes out and the finish button appears.

The current trend in Instructional Online Games (GOI) or game-based learning is that game-based learning attracts attention because of its increased positive effectiveness in promoting student engagement, motivation, and learning outcomes [8]. Game based learning generally involves students in different types of games to be played with different learning goals that seek to develop their cognitive abilities [12]. Game-based learning is considered to have the potential to introduce an environment based on several key aspects: giving students' challenges to overcome, enabling students to combine previous knowledge from different aspects to make meaningful decisions, and encourage students to predict what will happen as a result of decisions and action [4]. These aspects are consistent with important elements of building a game learning environment [10].

\subsection{MOOS for 21st-Century Careers: Creativity Skill (21-CC:CS)}

21st-Century Careers needed for education and the workplace today to support a disruption-era economy. To define and arrange these skills consists of three types of skills: learning skills (creativity and innovation; critical thinking and problem solving; communication and collaboration), literacy skills (information literacy; media literacy; ICT Literacy), and life skills (flexibility and adaptability; self-initiative and direction; social and cross-cultural skills; productivity and accountability; leadership and responsibility). 21st Century Skills are grouped into 10 skills in four categories: ways of thinking (creativity and innovation; critical thinking, problem solving, and decision making; learning and metacognition), work methods (communication; collaboration), tools for work (information literacy; ICT literacy), and life in the world 
(citizenship; life and career skills; personal and social responsibility) [16].

The creativity is very important, because creativity is a capability that is very meaningful in the process of human life. Human creativity gave birth to a great creator who colored the history of human life with his spectacular works. What was created was an original work that was extraordinary and meaningful, so that people were impressed and pursued his work. Creativity is not just luck, but it is hard work that is realized. Failure for creative people is only a confounding variable for success. He will try again, and try again until successful. Creative people use the knowledge we all have and make the leaps that are possible, they see things in new ways. Creativity is an idea is a new combination of old elements. There are no new elements, there are only new combinations. Creativity is creativity and the ability to create something from nothing to being. Typically, creativity will bring up innovation, namely the ability to renew things that already exist. If creativity is power or ability, innovation is the result or product.

The 21st-Century Careers: Creativity Skill (21-CC:CS) is a cognitive skill to bring up and develop new ideas, new ideas as the development of an idea that has been born before and skills to solve divergent problems of various points of view. In this research measured, creative thinking skills includes four aspects: (1) fluency (thinking smoothly), (2) flexibility (thinking, flexible), (3) originality (originality of thinking), (4) elaboration (decomposition). To measure this creative thinking skill description tests is used to obtain data creative thinking skills before and after learning.

Table 2: Normalized Gain Score $<\mathrm{g}>$ Each aspect $21 \mathrm{CC}$ : CS

\begin{tabular}{|l|l|l|l|l|}
\hline $\begin{array}{c}\text { 21 CC: CS } \\
\text { Indicator }\end{array}$ & $\begin{array}{c}\text { \% } \\
\text { Pre-test } \\
\text { average } \\
\text { score }\end{array}$ & $\begin{array}{c}\text { \% } \\
\text { Pre-test } \\
\text { average } \\
\text { score }\end{array}$ & $\langle$ g> & Category \\
\hline $\begin{array}{l}\text { Ask } \\
\text { questions }\end{array}$ & 45.5 & 92.5 & 0.86 & High \\
\hline $\begin{array}{l}\text { Guess the } \\
\text { causes }\end{array}$ & 42.5 & 87.5 & 0.7 & Moderate \\
\hline $\begin{array}{l}\text { Assess the } \\
\text { consequences } \\
\text { of an event }\end{array}$ & 41.5 & 85,8 & 0.6 & Moderate \\
\hline $\begin{array}{l}\text { Improve the } \\
\text { outputs }\end{array}$ & 40 & 83.73 & 0.5 & Moderate \\
\hline $\begin{array}{l}\text { Exceptional } \\
\text { use }\end{array}$ & 38 & 82.13 & 0.3 & Low \\
\hline Forecasting & 33 & 76.5 & 0.3 & Low \\
\hline
\end{tabular}

Every aspect of 21-CS:CC student creativity has increased as shown in Table 2. To solve questions type, ask questions, students get the highest score and based on normalized gain calculation results, aspects this also has the highest increase. Guess the causes, Assess the Consequences of an event, Improve the output gain which is being. The lowest gain increase in the lowest Exceptional use and Forecasting aspects. Most students still experience difficulty in working on the lowest usage and Forecasting types. This is possible because students still dwell on the process of memorizing physical material so their ability to innovate or imagine creating an idea the new one is still weak.

In general, the aspects of Exceptional use and Forecasting has the smallest increase possible because students are not accustomed to expressing many similar answers and ideas to problem. As for the test results, aspects Exceptional use and forecasting in the average pre-test are good enough when compared to the aspects other, so when compared with the results of the post-test the increase is not too large. So that this aspect can be further explored, class management should be considered well, all student groups must be payed to have a chance same in sparking ideas and answer the question, hereby expected students accustomed to expressing their ideas with smoothly.

Guess the causes, Assess the Consequences of an event and Improve the outputs ranking second because at the time of learning lasted students are indeed still difficult to give and reveal ideas vary when given the problem. Besides that, in answering the calculation application questions that demand students provide several alternatives the answer using the method only a few students differ able to answer more than one answer. Improved aspects of Ask questions occupy Highest original thinking skills what is seen is thinking about the problem or things that nobody else thought of as well able to express it in front of students other. The aspect that has the most improvement High is elaboration i.e. Skill to describe something in detail. In learning activities using GOOPI students are trained to develop an inquiry sparked in an online game and detailed it to in the work step to do the investigation, conducted an experiment according to the description they made themselves.

\section{CONCLUSION}

The creativity is essentially a person's ability to give birth to something new, both in the form of ideas and real work, both in new works and in combination with things that already exist, all of which are relatively different from what was before. Understanding creativity shows that there are three abilities that are related to the ability to combine, solve or answer problems, and reflect the operational abilities of creative student. Using the GOOPI for an increase of $21 \mathrm{CC}$ : CS students in the moderate category after learning to use GOOPI, this significant improvement showed the effectiveness of GOOPI in facilitating student learning to improve creative thinking skills. The conclusion of this study is the Open Online Physics Instructional Game for Improving $21 \mathrm{CC}$ :CS. Some suggestions put forward by researchers include the teacher should pay attention to each skill student groups so that initial abilities are possessed students can be well honed and experienced a significant increase. For further researchers are expected to conduct research on more scope broad, different school levels and material different, as well as for future researchers expected to develop aspects others are complete and more detailed. 


\section{ACKNOWLEDGMENTS}

The research was funded by research grant at the Institute for Research and Community Services, Universitas Negeri Jakarta, Ministry of Education and Culture, Indonesia, 2020.

\section{REFERENCES}

1. Wilkesmann, M., \& Wilkesmann, U. (2018). Industry 4.0 - organizing routines or innovations?. VINE Journal of Information and Knowledge Management Systems, 48(2), pp. 238-254.

https://doi.org/10.1108/VJIKMS-04-2017-0019

2. Catal, C., \& Tekinerdogan, B. (2019). Aligning Education for the Life Sciences Domain to Support Digitalization and Industry 4.0. Procedia Computer Science, 158, pp. 99-106. https://doi.org/10.1016/j.procs.2019.09.032

3. Chai, C. S., Hwee Ling Koh, J., \& Teo, Y. H. (2018). Enhancing and Modeling Teachers' Design Beliefs and Efficacy of Technological Pedagogical Content Knowledge for 21st Century Quality Learning. Journal of Educational Computing Research, 073563311775245 .

https://doi.org/10.1177/0735633117752453

4. Cicchino, M. I. (2015). Using game-based learning to foster critical thinking in student discourse. Interdisciplinary Journal of Problem-based Learning, 9(2), pp. 1-13.

https://doi.org/10.7771/1541-5015.1481

5. Hamalainen, R. H., Niilo-Rama, M., Lainema, T., \& Oksanen, K. (2018). How to raise different game collaboration activities: The association between game mechanics, players' roles and collaboration processes. Simulation \& Gaming, 49, pp. 50-71.

6. Hsu, C.-C., \& Wang, T.-I. (2018). Applying game mechanics and student-generated questions to an online puzzle-based game learning system to promote algorithmic thinking skills. Computers \& Education, 121, pp. 73-88.

https://doi.org/10.1016/j.compedu.2018.02.002

7. Huda, M. (2018). Empowering application strategy in the technology adoption. Journal of Science and Technology Policy Management. 09, 0044

8. Jong, M. S. Y. (2015). Does online game-based learning work in formal education at school? A case study of VISOLE. Curriculum Journal, 26(2), pp. 249-267.

9. Kåre Letrud \& Sigbjørn Hernes. (2018). Excavating the origins of the learning pyramid myths, Cogent Education, 5:1, pp. 1518638.

https://doi.org/10.1080/2331186X.2018.1518638

10. Klymchuk, S. (2017). Puzzle-based learning in engineering mathematics: Students' attitudes. International Journal of Mathematical Education in Science and Technology, pp. 1-14.

11. Melko, R. G., Carleo, G., Carrasquilla, J., \& Cirac, J. I. (2019). Restricted Boltzmann machines in quantum physics. Nature Physics. pp. 1-9.
12. Plass, J. L., Homer, B. D., \& Kinzer, C. K. (2015). Foundations of game-based learning. Educational Psychologist, 50 (4), pp. 258-283. https://doi.org/10.1080/00461520.2015.1122533

13. Qian, M., \& Clark, K. R. (2016). Game-based Learning and 21st century skills: A review of recent research. Computers in Human Behavior, 63, pp. 50-58.

14. Richey, R.C, Klein, J.D. Tracey, (2019). The Instructional Design Knowledge Base: Theory, Research, and Practice. Publisher: Taylor \& Francis.

15. Srisawasdi, N., \& Panjaburee, P. (2018). Implementation of Game-transformed Inquiry-based Learning to Promote the Understanding of and Motivation to Learn Chemistry. Journal of Science Education and Technology. pp. 1-13.

16. Van Laar, E., van Deursen, A. J. A. M., van Dijk, J. A. G. M., \& de Haan, J. (2020). Measuring the levels of 21st-century digital skills among professionals working within the creative industries: A performance-based approach. Poetics, 101434. https://doi.org/10.1016/j.poetic.2020.101434

17. Waite, A. M., \& McDonald, K. S. (2018). Exploring Challenges and Solutions Facing STEM Careers in the 21st Century: A Human Resource Development Perspective. Advances in Developing Human Resources, 152342231881448.

18. Wechslera, S. A., Carlos Saizb, Silvia F. Rivasb,Claudete Maria Medeiros Vendraminic, Leandro S. Almeidad, Maria Celia Mundima, Amanda Francod. (2018). Creative and critical thinking: Independent or overlapping components?. Thinking Skills and Creativity. 27, pp. 114-122. https://doi.org/10.1016/j.tsc.2017.12.003

19. Wibowo, Firmanul Catur, Andi Suhandi, Nahadi Nahadi, Bayram Coştu. (2017). Virtual Microscopic Simulation (VMS) to promote students' conceptual change: A case study of heat transfer. Asia-Pacific Forum on Science Learning and Teaching. 18(2), pp. 1-32.

20. Anagün, Ş. S. (2018). Teachers' Perceptions about the Relationship between 21st Century Skills and Managing Constructivist Learning Environments. International Journal of Instruction, 11(4), pp. 825-840.

21. Zuo, X., Chen, R., Zhang, D., Ke, P., \& Wang, A. (2019). Movement of luminous group spots on target and size modification of micro-particles during cathodic vacuum arc deposition. Vacuum, 164, pp. 381-389. https://doi.org/10.1016/j.vacuum.2019.03.048

22. Alrfooh A., M., Lakulu, m. m., (2020). The Effect of Electronic Educational Assessment Environment (Navigation and Content) on Students' Intention to use Mobile Based Assessment. International Journal of Advanced Trends in Computer Science and Engineering. 9(1), pp. 440-453. https://doi.org/10.30534/ijatcse/2020/61912020

23. Hachmoud, S., Hachmoud, A., Meddaoui, A., Allali, H., (2019). Analysis of Students Online Learning Behavior in a Pedagogical Model combining Blended Learning and Competency Based Approach. 
International Journal of Advanced Trends in Computer Science and Engineering. 8(6), pp. 3389-3395.

https://doi.org/10.30534/ijatcse/2019/113862019

24. Akharraz, L., Saoud, S., Mezouary, A., E., (2019). New Approach for Context-dependent Learner Model for Technology Enhanced Learning System. International Journal of Advanced Trends in Computer Science and Engineering. 8(4), pp. 1711-1718.

https://doi.org/10.30534/ijatcse/2019/99842019 